
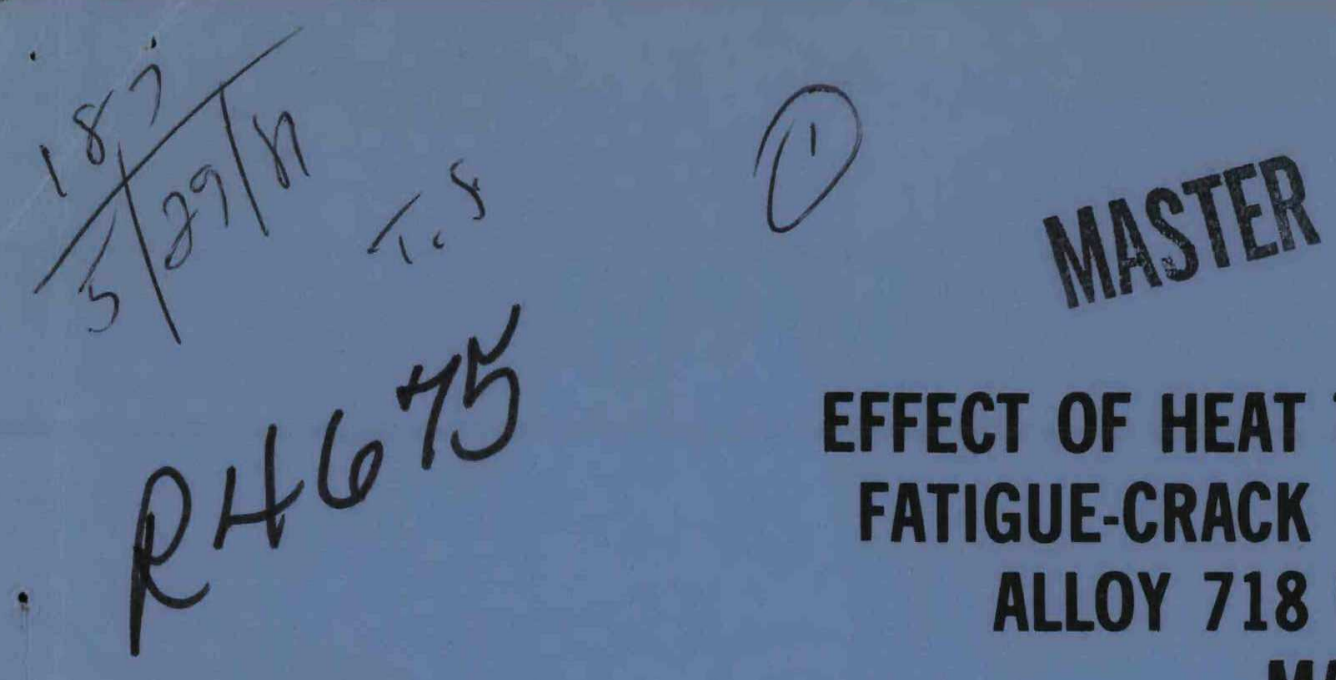

Ah. 2679

HEDL-TME $81-12$ UC-79b,h

\title{
EFFECT OF HEAT TREATMENT UPON THE FATIGUE-CRACK GROWTH BEHAVIOR OF ALLOY 718 WELDMENTS -- PART I, MACROSCOPIC BEHAVIOR
}

\section{DO NOT MICROFLM}

COVER

\section{Hanford Engineering Development Laboratory}

\section{DISTRIBUTION OF THIS DOCUMENT IS UNLIMITED}

HANFORD ENGINEERING DEVELOPMENT LABORATORY

Operated by Westinghouse Hanford Company

P.0. Box 1970 Richland, WA 99352

A Subsidiary of Westinghouse Electric Corporation

Prepared for the U.S. Department of Energy under Contract No. DE-AC1476FF02170 


\section{DISCLAIMER}

This report was prepared as an account of work sponsored by an agency of the United States Government. Neither the United States Government nor any agency Thereof, nor any of their employees, makes any warranty, express or implied, or assumes any legal liability or responsibility for the accuracy, completeness, or usefulness of any information, apparatus, product, or process disclosed, or represents that its use would not infringe privately owned rights. Reference herein to any specific commercial product, process, or service by trade name, trademark, manufacturer, or otherwise does not necessarily constitute or imply its endorsement, recommendation, or favoring by the United States Government or any agency thereof. The views and opinions of authors expressed herein do not necessarily state or reflect those of the United States Government or any agency thereof. 


\section{DISCLAIMER}

Portions of this document may be illegible in electronic image products. Images are produced from the best available original document. 


\section{NOTICE}

This report was prepared as an account of work sponsored by the United States Government. Neither the United States nor the U.S. Department of Energy (DOE), nor any of its employes, nor any of its contractors, subcontractors or their employes, makes any warranty, expressed or implied, or assumes any legal liability or responsibility for any third party's use or the results of such use of any information, apparatus, product or process disclosed in this report, or represents that its use by such third party would not infringe privately owned rights.

Printed in the United States of America

Available from

DOE Technical Information Center

P.O. Box 62

Oak Ridge, TN 37830

NTIS price codes

Printed Copy: $\mathrm{A} 03$

Microfiche copy: A01 


\section{EFFECT OF HEAT TREATMENT UPON THE FATIGUE-CRACK GROWTH BEHAVIOR OF ALLOY 718 WELDMENTS -- PART I, MACROSCOPIC BEHAVIOR}

\section{Hanford Engineering Development Laboratory}

L.A. James

W.J. Mills

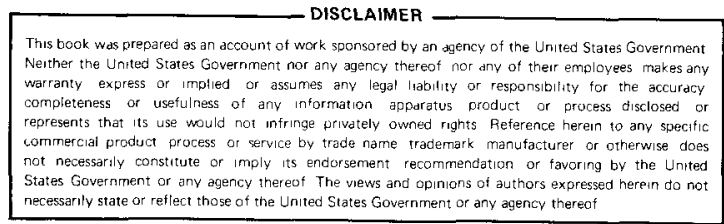

May 1981

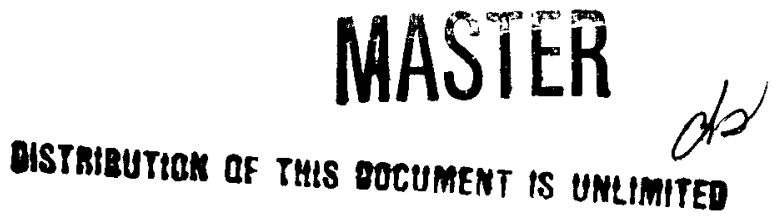

HANFORD ENGINEERING DEVELOPMENT LABORATORY

Operated by Westinghouse Hanford Company

P.0. Box 1970 Richland, WA 99352

A Subsidiary of Westinghouse Electric Corporation

Prepared for the U.S. Department of Energy under Contract No. DE-AC1476FF02170 


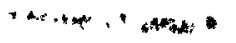

4. "

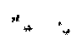


HEDL-TME $81-12$

UC-79b, h

EFFECT OF HEAT-TREATMENT UPON THE FATIGUE-CRACK GROWTH BEHAVIOR

OF ALLOY 718 WELDMENTS - PART I: MACROSCOPIC BEHAVIOR

L. A. James

W. J. Mills

\begin{abstract}
Gas-tungsten-arc weldments in Alloy 718 were studied in fatigue-crack growth tests conducted at five temperatures over the range $24-649^{\circ} \mathrm{C}$. In general, crack growth rates increased with increasing temperature, and weldments given the "conventional" post-weld heat-treatment generally exhibited crack growth rates that were higher than for weldments given the "modified" (INEL) heat-treatment. Limited testing in the as-welded condition revealed crack growth rates significantly lower than observed for the heat-treated cases, and this was attributed to residual stresses. Three different heats of filler wire were utilized, and no heat-to-heat variations were noted.
\end{abstract}

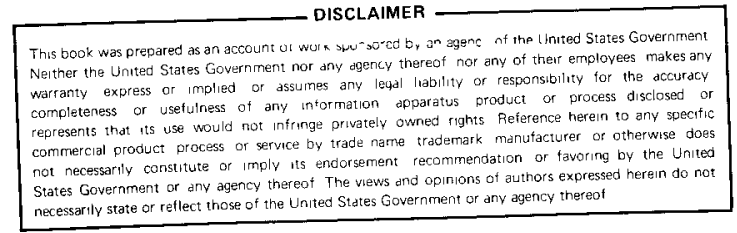




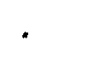




\section{CONTENTS}

\begin{tabular}{|c|c|c|}
\hline & & Page \\
\hline & Abstract & $\mathrm{iii}$ \\
\hline & Figures & vi \\
\hline & Tables & vii \\
\hline I. & INTRODUCTION & 1 \\
\hline II. & EXPERIMENTAL PROCEDURE & 3 \\
\hline III. & RESULTS AND DISCUSSION & 11 \\
\hline & A. PRECIPITATION HEAT-TREATED MATERIAL & 11 \\
\hline & B. AS-WELDED MATERIAL & 20 \\
\hline IV. & CONCLUSIONS & 25 \\
\hline V. & REFERENCES & 27 \\
\hline
\end{tabular}




\section{FIGURES}

Figure Page

1 Typical Weld Joint Details 4

2 Fatigue-Crack Growth Specimen 4

3 Fatigue-Crack Growth Rate Behavior of Alloy 718 Weldments Tested in Air at $24^{\circ} \mathrm{C}$

4 Fatigue-Crack Growth Rate Behavior of Alloy 718 Weldments Tested in Air at $316^{\circ} \mathrm{C}$

5 Fatigue-Crack Growth Rate Behavior of Alloy 718 Weldments Tested in Air at $427^{\circ} \mathrm{C}$

6 Fatigue-Crack Growth Rate Behavior of Alloy 718 Weldments Tested in Air at $538^{\circ} \mathrm{C}$

7 Fatigue-Crack Growth Rate Behavior of Alloy 718 Weldments Tested in Air at $649^{\circ} \mathrm{C}$

8 Fatigue-Crack Growth Rate Behavior of Alloy 718 Weldments in the As-Welded Condition Tested in Air at $24^{\circ} \mathrm{C}$ and $427^{\circ} \mathrm{C}$

9 Fatigue-Crack Growth Rate Behavior of Alloy 718 Weldments in the As-Welded Condition Tested in Air at $538^{\circ} \mathrm{C}$ and $649^{\circ} \mathrm{C}$ 


\section{TABLES}

Table $\quad \underline{\text { Page }}$

1 Identification of Material Heats 5

2 Chemical Composition (Percent by Weight) 6

3 Summary of Specimen Dimensions and Test Parameters 7

4 Post-Weld Precipitation Heat Treatments for Alloy $718 \quad 8$

5 Average Mechanical Properties 9

6 Crack Growth Equation Constants 18 


\section{EFFECT OF HEAT-TREATMENT UPON THE FATIGUE-CRACK GROWTH BEHAVIOR}

\section{OF ALLOY 718 WELDMENTS - PART I: MACROSCOPIC BEHAVIOR}

\section{INTRODUCTION}

Alloy 718 is a precipitation-hardenable nickel-base superalloy that is employed extensively in structural applications in the nuclear, aerospace, and petrochemical industries where high strength, creep resistance, and corrosion resistance at elevated temperatures are important design considerations. Such structures are often subjected to cyclic loadings in service, and the possibility therefore exists for subcritical extension of defects, should such defects be present in the appropriate size, shape, and location. The analysis techniques of linear-elastic fracture mechanics (LEFM) are quite useful in estimating the in-service extension of such flaws, but their usage requires knowledge of the fatigue-crack propagation (FCP) behavior of the structural alloy tested under the appropriate conditions. Since many structural designs employ welding as the main method of joining components, knowledge of the crack growth behavior in weldments is usually necessary.

Some characterization of the FCP behavior of weldments in Alloy 718 at elevated temperatures has already been accomplished. Popp and Coles ${ }^{(1)}$ studied the crack growth behavior in Alloy 718 sheet, weld metal, and heat-affected zones (HAZ) at a temperature of $538^{\circ} \mathrm{C}\left(1000^{\circ} \mathrm{F}\right)$, and concluded that there was no significant difference in the behavior of the three locations. Previous results at HEDL ${ }^{(2-4)}$ showed crack growth rates to be higher in the weld metal than in the parent metal over the temperature range $24-649^{\circ} \mathrm{C}\left(75-1200^{\circ} \mathrm{F}\right)$, and that the behavior was affected by the post-welding heat-treatment employed. Other studies at HEDL have examined the crack growth behavior of Alloy 718 weldments containing weld defects ${ }^{(5)}$ (e.g., porosity and inclusions) or the effect of fast-neutron irradiation upon the crack growth behavior of Alloy 718 weldments. ${ }^{(6)}$ Specimens employing Alloy 718 welded to either Alloy 600 or Type 316 stainless steel (Alloy 82 filler metal was 
used in both cases) exhibited $\mathrm{FCP}$ rates at $427^{\circ} \mathrm{C}\left(800^{\circ} \mathrm{F}\right)$ and $538^{\circ} \mathrm{C}\left(1000^{\circ} \mathrm{F}\right)$ that were approximately the same whether the crack grew in the weld metal or in one of the parent metals. (7) In addition, considerable work has been done at HEDL characterizing the effect of various parameters upon the FCP behavior of wrought Alloy 718 . $^{(2,6,8-13)}$

The present study expands upon the earlier results of Refs. 2-4 by adding data for different heats of filler metal, as well as studying additional test temperature/heat-treatment combinations. This report will describe the macroscopic behavior of the weldments. The microscopic features of the fracture processes will be discussed in the companion paper. (14) 


\section{EXPERIMENTAL PROCEDURE}

A11 welds used in the present study were produced using the gas-tungsten-arc (GTA) welding process*, and were of the vee-groove design as shown in Figure 1. Three different heats of filler metal (designated Heats "G", "J", and "K" in Table 1) were employed, as well as several heats of parent metal (designated Heats "G", "H", and "I" in Table 1, and Heats "A" and "E" in a similar table in Ref. 11). See Table 2 for chemical compositions of the heats. ASTM Compact Specimens (see ASTM E647-78T) were machined from the weldments and oriented such that the notch was centered in the weid metal and the resulting crack propagation direction was parallel to the direction of welding (Figure 2). Three sizes of specimens were utilized, with width dimensions ("W") of either $29.3 \mathrm{~mm}$ (1.154 inch), $38.1 \mathrm{~mm}$ (1.50 inch), or $50.8 \mathrm{~mm}$ (2.00 inch), and thickness dimensions of either $7.62 \mathrm{~mm}(0.30$ inch) or 11.4-12.7 mm (0.45-0.50 inch). See Table 3 for a detailed listing of specimen sizes and test parameters. The heat designation applied to each specimen is as follows: the first letter denotes the heat of filler metal used, the second letter is the heat of base metal employed. All welds were given a radiographic inspection and found to be sound.

The welds were produced with the parent material in the annealed condition, and then given a post-welding precipitation heat-treatment. Two different post-weld heat-treatments were employed: the "conventional" heat-treatment (CHT) as found in ASTM A637 and AMS 5596, and a "modified" heat-treatment (MHT) that was developed at the Idaho National Engineering Laboratory (INEL) to improve the toughness of Alloy 718 weldments. $(15,16)$ The two heattreatments are detailed in Table 4. In addition, a few specimens were tested in the as-welded condition. Typical mechanical properties for the various material conditions are given in Table 5 .

*Welds were produced at INEL on an automatic welding machine in the flat position. Parameters for Heat $G / G$ welds (reasonably typical for the other welds) are: Current Range $=155-175$ amps; Voltage $=8.7-8.8 \mathrm{v}$; Travel Speed $=33-38 \mathrm{~mm} / \mathrm{minute}$; Wire Feed Speed $=686-864 \mathrm{~mm} / \mathrm{minute}$; Wire Diameter $=1.14 \mathrm{~mm}$. 


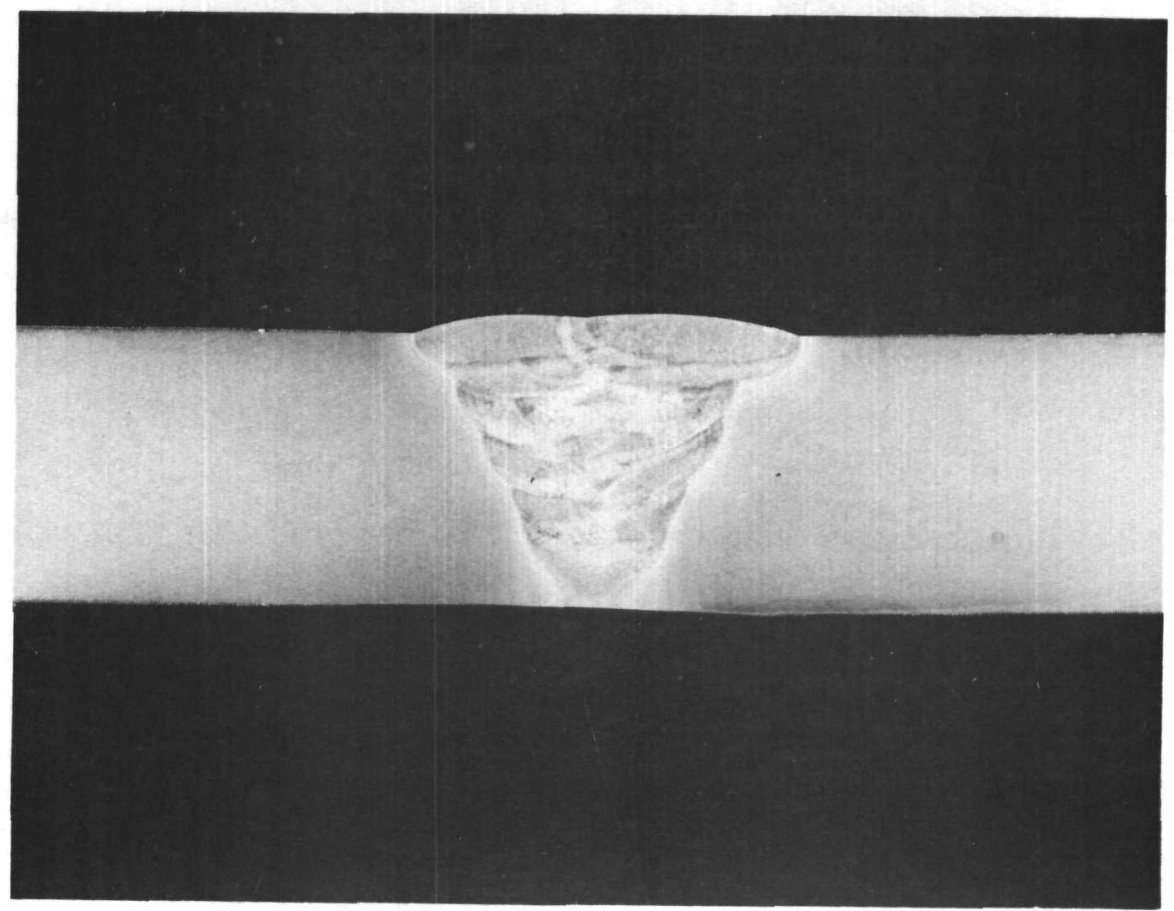

FIGURE 1. Typical Weld Joint Details. (Neg. 792304B)

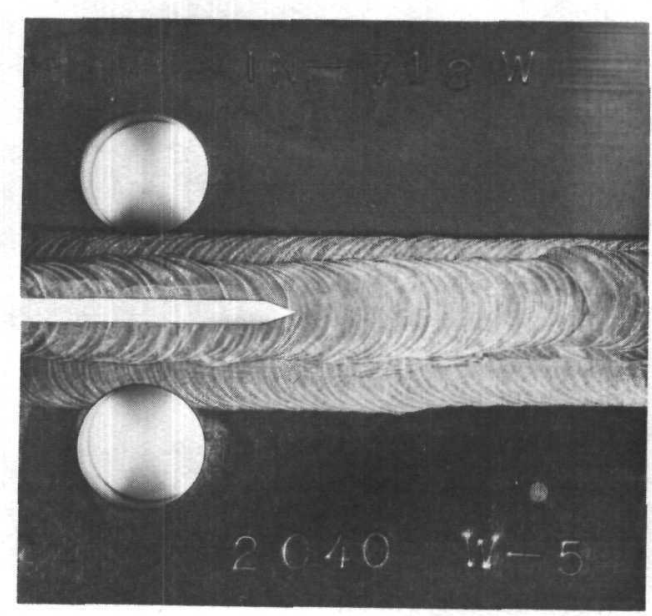

FIGURE 2. Fatigue-Crack Growth Specimen. (Neg. 791946) 


\section{TABLE 1}

IDENTIFICATION OF MATERIAL HEATS $(a)$

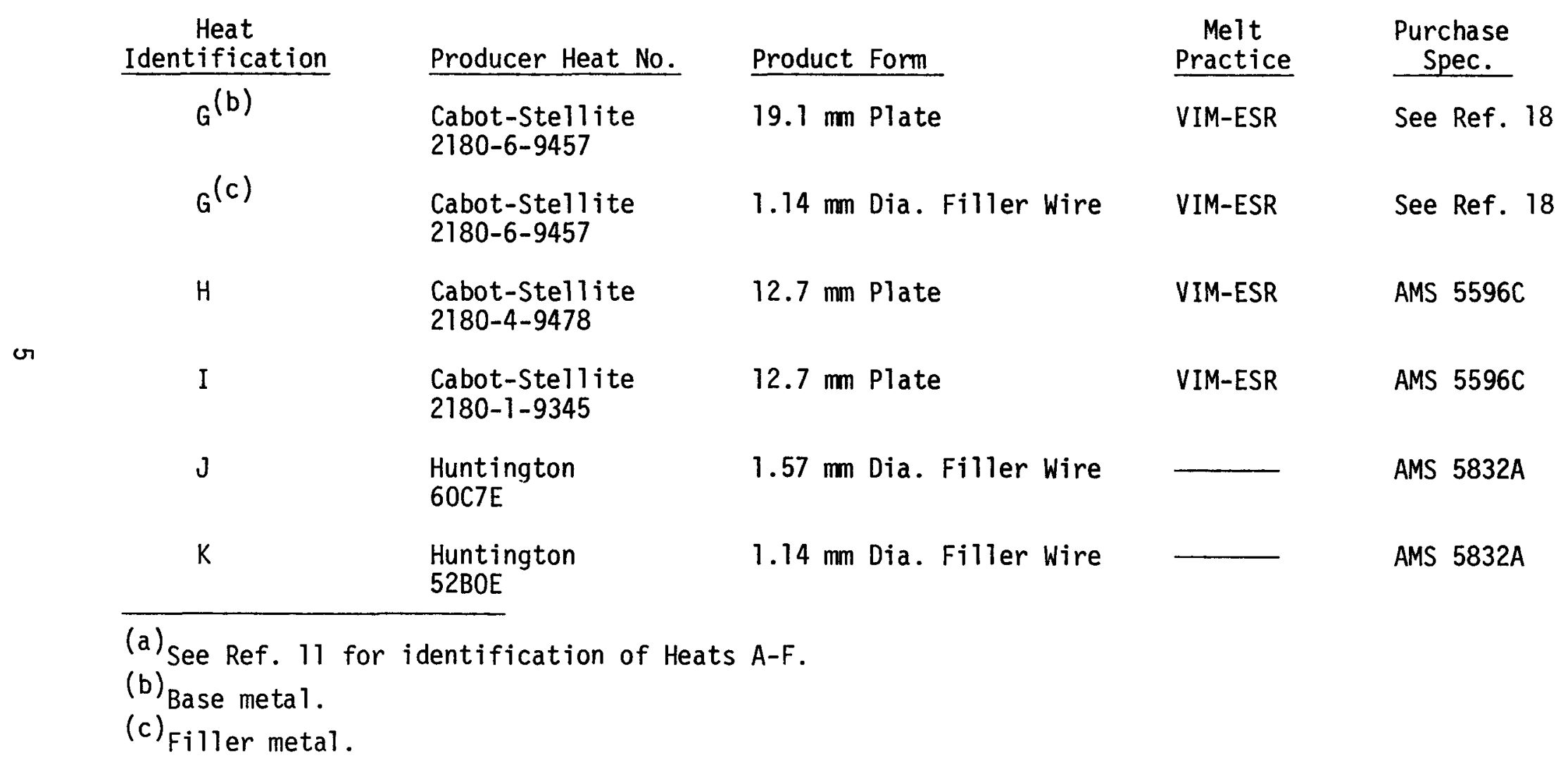


TABLE 2

CHEMICAL COMPOSITION (PERCENT BY WEIGHT) ${ }^{(a)}$

\begin{tabular}{|c|c|c|c|c|c|c|c|c|c|c|c|c|c|c|c|c|c|}
\hline $\begin{array}{c}\text { Heat } \\
\text { Ident. }\end{array}$ & $C$ & $\mathrm{Mn}$ & $\mathrm{Fe}$ & $S$ & Si & $\mathrm{Cu}$ & $\mathrm{Ni}$ & $\mathrm{Cr}$ & $\mathrm{Al}$ & Ti & Co & $P$ & Mo & $B$ & Cb\&Ta & $\mathrm{Cb}$ & $\mathrm{Ta}$ \\
\hline$G^{(b)}$ & .05 & .32 & 19.10 & $<.002$ & .17 & .03 & 51.86 & 18.20 & .59 & 1.05 & $<.05$ & $<.005$ & 3.03 & .002 & 5.13 & * & $<.10$ \\
\hline$H$ & .05 & .21 & Bal. & .005 & .10 & .02 & 52.63 & 18.21 & .54 & .97 & .30 & .005 & 3.05 & .002 & 5.08 & * & * \\
\hline$k$ & .04 & .04 & 17.60 & .007 & .19 & .05 & 54.58 & 17.91 & .49 & .99 & .04 & .011 & 2.96 & .0031 & 5.08 & 5.07 & .01 \\
\hline
\end{tabular}

*Not determined.

(a) See Ref. 11 for chemical compositions of Heats A-F.

(b) $19.1 \mathrm{~mm}$ plate.

(c) $1.14 \mathrm{~mm}$ dia. filler wire. 
TABLE 3

SUMMARY OF SPECIMEN DIMENSIONS AND TEST PARAMETERS

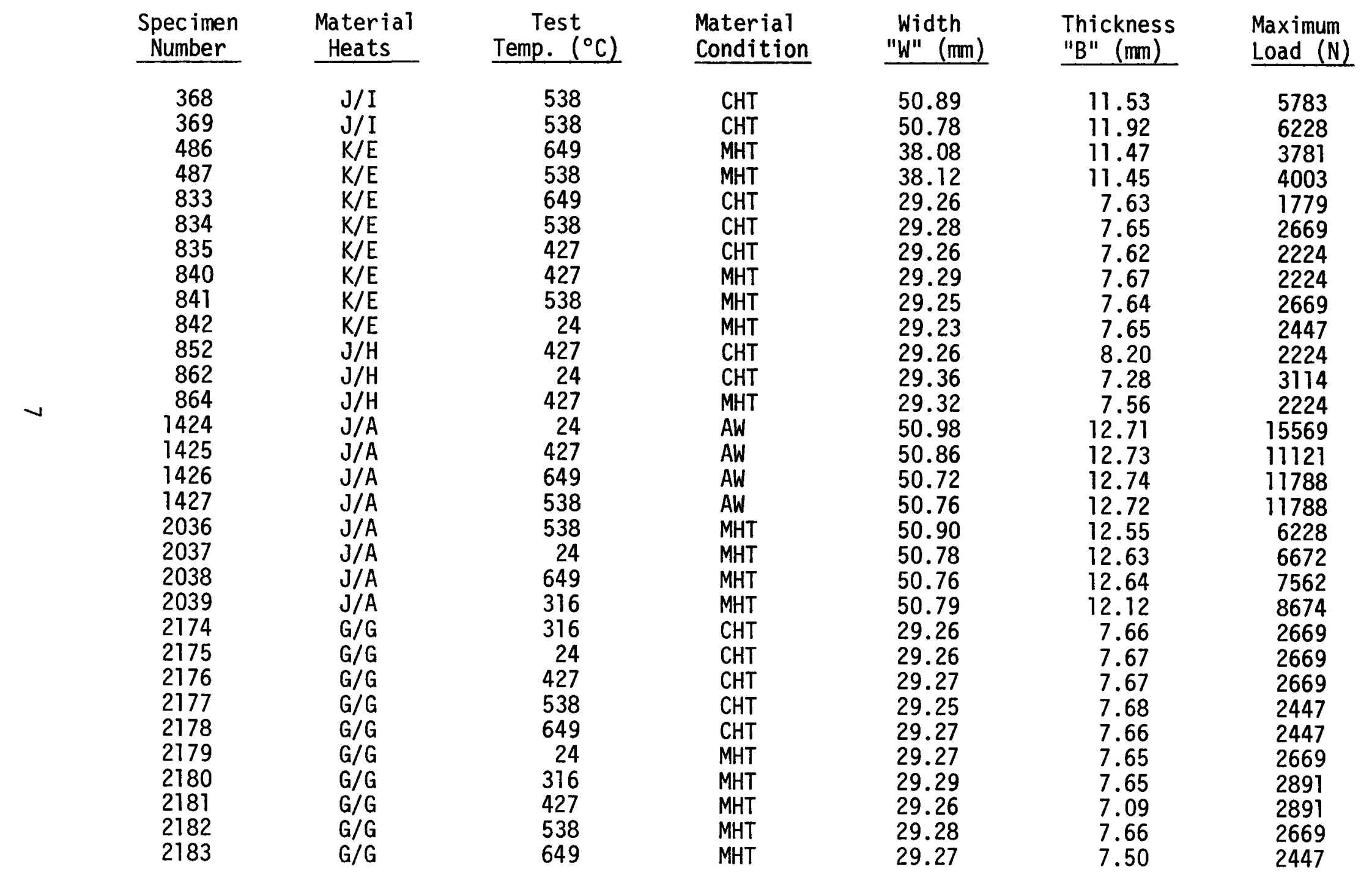




\section{TABLE 4}

POST-WELD PRECIPITATION HEAT TREATMENTS FOR ALLOY 718

\section{Conventional Heat Treatment}

Annealed at $954^{\circ} \mathrm{C}$, air cooled to room temperature.

Aged 8 hours at $718^{\circ} \mathrm{C}$, furnace cooled to $621^{\circ} \mathrm{C}$ and held at $621^{\circ} \mathrm{C}$ for a total aging time of 18 hours.

Air cooled to room temperature.

Modified Heat Treatment

Solution annealed 1 hour at $1093^{\circ} \mathrm{C}$, cooled to $718^{\circ} \mathrm{C}$ at $55^{\circ} \mathrm{C} /$ hour . Aged 4 hours at $718^{\circ} \mathrm{C}$, cooled to $621^{\circ} \mathrm{C}$ at $55^{\circ} \mathrm{C} /$ hour.

Aged 16 hours at $627^{\circ} \mathrm{C}$, air cooled to room temperature. 
TABLE 5

AVERAGE MECHANICAL PROPERTIES $(a)$

\begin{tabular}{|c|c|c|c|c|c|c|c|c|}
\hline $\begin{array}{l}\text { Heat } \\
\text { Ident. }\end{array}$ & $\begin{array}{l}\text { Material } \\
\text { Condition } \\
\end{array}$ & $\begin{array}{l}\text { Test } \\
\text { Temp. } \\
\left({ }^{\circ} \mathrm{C}\right) \\
\end{array}$ & $\begin{array}{l}0.2 \% \text { Yield } \\
\text { Strength } \\
(\mathrm{MPa}) \\
\end{array}$ & $\begin{array}{l}\text { Ultimate } \\
\text { Strength } \\
\text { (MPa) } \\
\end{array}$ & $\begin{array}{l}\text { Uniform } \\
\text { Elong. } \\
(\%) \\
\end{array}$ & $\begin{array}{l}\text { Total } \\
\text { Elong. } \\
(\%) \\
\end{array}$ & $\begin{array}{c}\text { Red. in } \\
\text { Area } \\
(\%) \\
\end{array}$ & $\begin{array}{r}\text { No. of } \\
\text { Tests } \\
\end{array}$ \\
\hline G & MHT & 24 & 1026 & 1326 & (c) & 18.5 & (c) & 2 \\
\hline$J$ & As-Welded & 24 & 504 & 817 & 32.5 & 33.0 & 47.0 & 2 \\
\hline J & CHT & 24 & 1061 & 1273 & 13.5 & 13.6 & 17.4 & 3 \\
\hline J & MHT & 24 & 1047 & 1330 & 16.5 & 18.0 & 35.0 & 2 \\
\hline K & MHT & 24 & 970 & 1324 & (c) & 20.3 & 24.3 & $3^{(b)}$ \\
\hline J & As-Welded & 427 & 538 & 802 & 25.5 & 27.0 & 35.5 & 2 \\
\hline$J$ & $\mathrm{CHT}$ & 427 & 933 & 1108 & 15.2 & 17.5 & 20.2 & 3 \\
\hline J & MHT & 427 & 956 & 1236 & 14.5 & 16.5 & 37.5 & 2 \\
\hline$k$ & MHT & 427 & 872 & 1183 & (c) & 13.2 & 18.6 & $3^{(b)}$ \\
\hline G & MHT & 538 & 876 & 1134 & (c) & 15.0 & (c) & 2 \\
\hline J & As-Welded & 538 & 503 & 766 & 27.0 & 27.0 & 35.0 & 2 \\
\hline $\mathrm{J}$ & $\mathrm{CHT}$ & 538 & 912 & 1104 & 13.4 & 14.2 & 24.9 & 3 \\
\hline$J$ & MHT & 538 & 902 & 1170 & 15.0 & 16.5 & 35.0 & 2 \\
\hline
\end{tabular}

(a) Specimens oriented parallel to direction of welding and were comprised entirely of deposited filler metal.

(b) From Ref. 16 .

(c) Not reported. 
Fatigue cycling was done on servo-controlled MTS testing machines operating in the load-control mode using a sinusoidal waveform. All testing was done at a cyclic frequency of $0.667 \mathrm{~Hz}(40 \mathrm{cpm})$ except at room temperature where frequency is not expected to be an important variable. The stress ratio $\left(R=K_{\min } / K_{\max }\right)$ was 0.05 for all tests.

Tests were conducted at five temperatures: $24^{\circ} \mathrm{C}\left(75^{\circ} \mathrm{F}\right), 316^{\circ} \mathrm{C}\left(600^{\circ} \mathrm{F}\right)$, $427^{\circ} \mathrm{C}\left(800^{\circ} \mathrm{F}\right), 538^{\circ} \mathrm{C}\left(1000^{\circ} \mathrm{F}\right)$, and $649^{\circ} \mathrm{C}\left(1200^{\circ} \mathrm{F}\right)$. The specimens at elevated temperatures were tested in an air-circulating furnace where temperatures were controlled to within $\pm 1^{\circ} \mathrm{C}$.

In general, the testing and data analysis methods of ASTM E647-78T were employed in this study. LEFM validity was assured by limiting crack-tip plasticity in the uncracked ligaments by employing a "flow stress criterion". (17) Virtually all of the data reported in this study satisfied the flow stress criterion. Crack lengths were determined optically on both sides of each specimen using a travelling microscope. The average crack length was then used to calculate the stress intensity factor $(K)$ employing the formula given in ASTM E647-78T. The "secant method" was used to calculate crack growth rates $(d a / d N)$. The results were then plotted on logarithmic coordinates with $d a / d N$ as a function of $\Delta K$. Linear or bilinear lines were fitted through the data using least-squares regression analyses. 


\section{RESULTS AND DISCUSSION}

\section{A. PRECIPITATION HEAT-TREATED MATERIAL}

The results for precipitation heat-treated specimens are given in Figures 3-7. The format for each of these figures is the same: results for specimens given the conventional post-weld heat treatment are plotted on the left, while results for specimens given the modified post-weld heat-treatment are plotted on the right. Also shown, for comparison purposes, are regression lines from a similar study $(11)$ on heat-to-heat variations in wrought product forms (plate, bar, and forgings) of Alloy 718.

Comparing the least-squares regression lines for weldments and wrought Alloy 718 in Figures 3-7 shows that, in general, fatigue-crack growth rates are slightly higher in the weldments than in the wrought product forms (the results at $649^{\circ} \mathrm{C}$ are an exception to this general trend). Although the observation of higher crack growth rates in weldments is in agreement with previous results, $(2-4)$ the differences are not large and in some cases (e.g., see Figure 5a) the behavior is substantially identical over certain ranges of $\Delta K$.

It will be noted that in some of the curves (e.g., Figures $3 b, 4 a, 5 a, 5 b$, $6 a)$, the data for the weldment specimens exhibits a change to a steeper slope at the higher values of $\Delta K$. This sort of trend is fairly typical of crack growth rate curves for many types of materials, and is often associated with the approach to instability conditions (either in terms of fracture toughness, plastic limit load, etc.). The curves for the wrought product forms do not exhibit this tendency for a slope transition as strongly, and this is consistent with the observation that wrought forms of Alloy 718 generally have superior fracture toughness relative to weldments in Alloy 718. (19) It will also be noted that in two cases (see Figures $3 a$ and $4 b$ ), data points are plotted that are not included in the least-squares regressions. These excluded data represented accelerated crack growth behavior (leading to fracture at K-levels not greatly in excess 


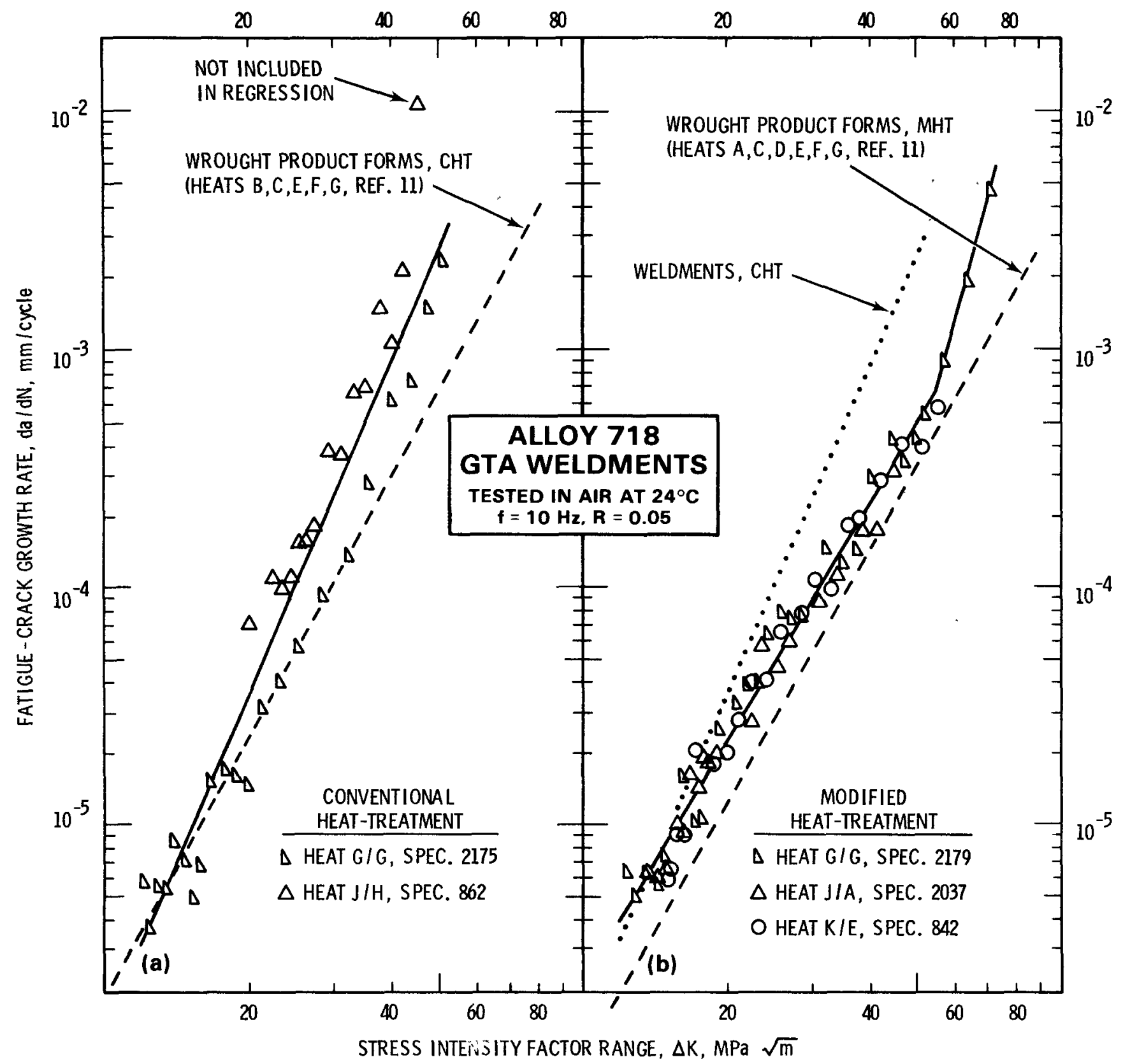

FIGURE 3. Fatigue-Crack Growth Rate Behavior of Alloy 718 Weldments Tested in Air at $24^{\circ} \mathrm{C}$. (Neg. 8009381-3) 


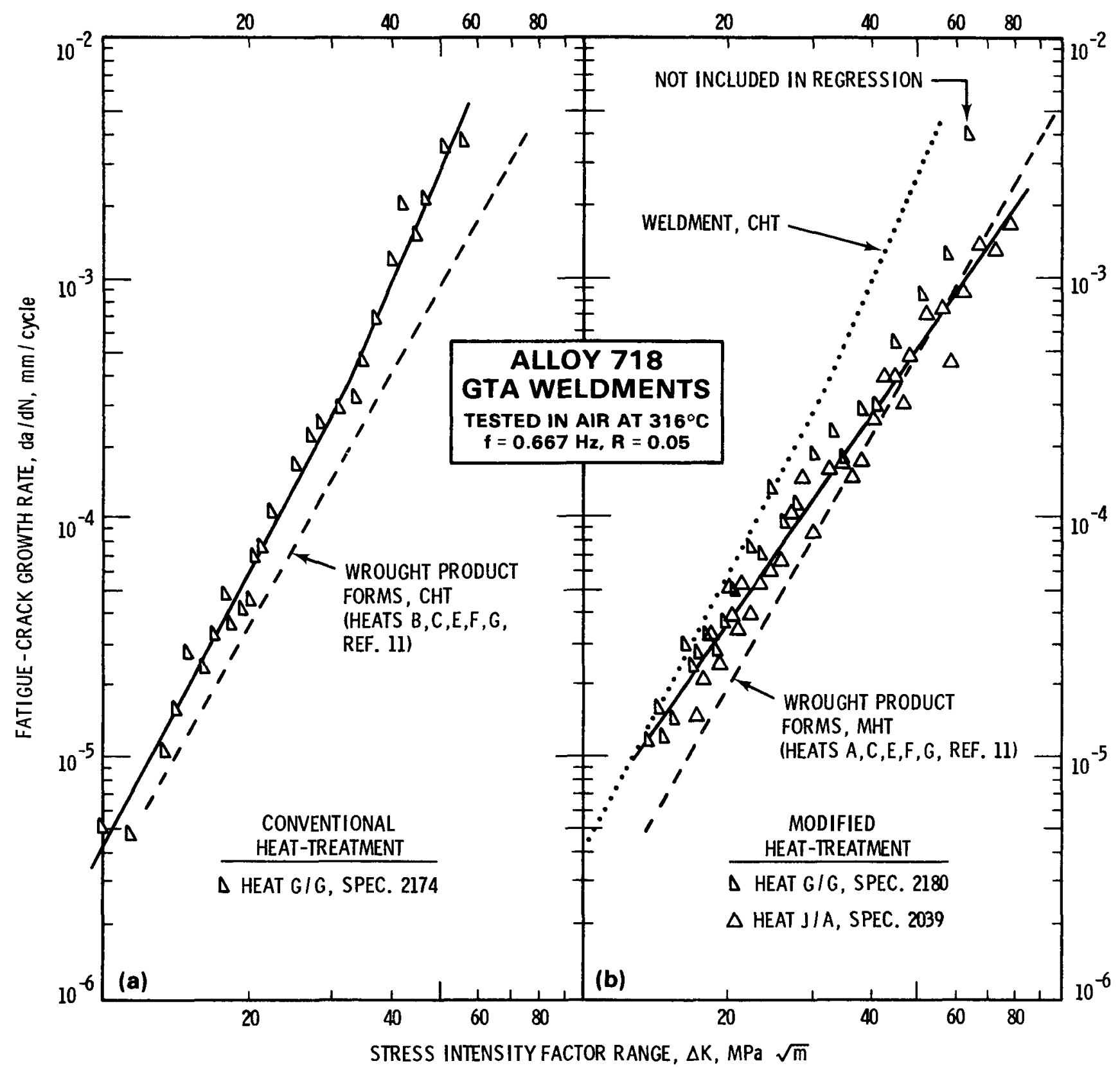

FIGURE 4. Fatigue-Crack Growth Rate Behavior of Alloy 718 Weldments Tested in Air at $316^{\circ} \mathrm{C}$. (Neg. 8009381-7) 


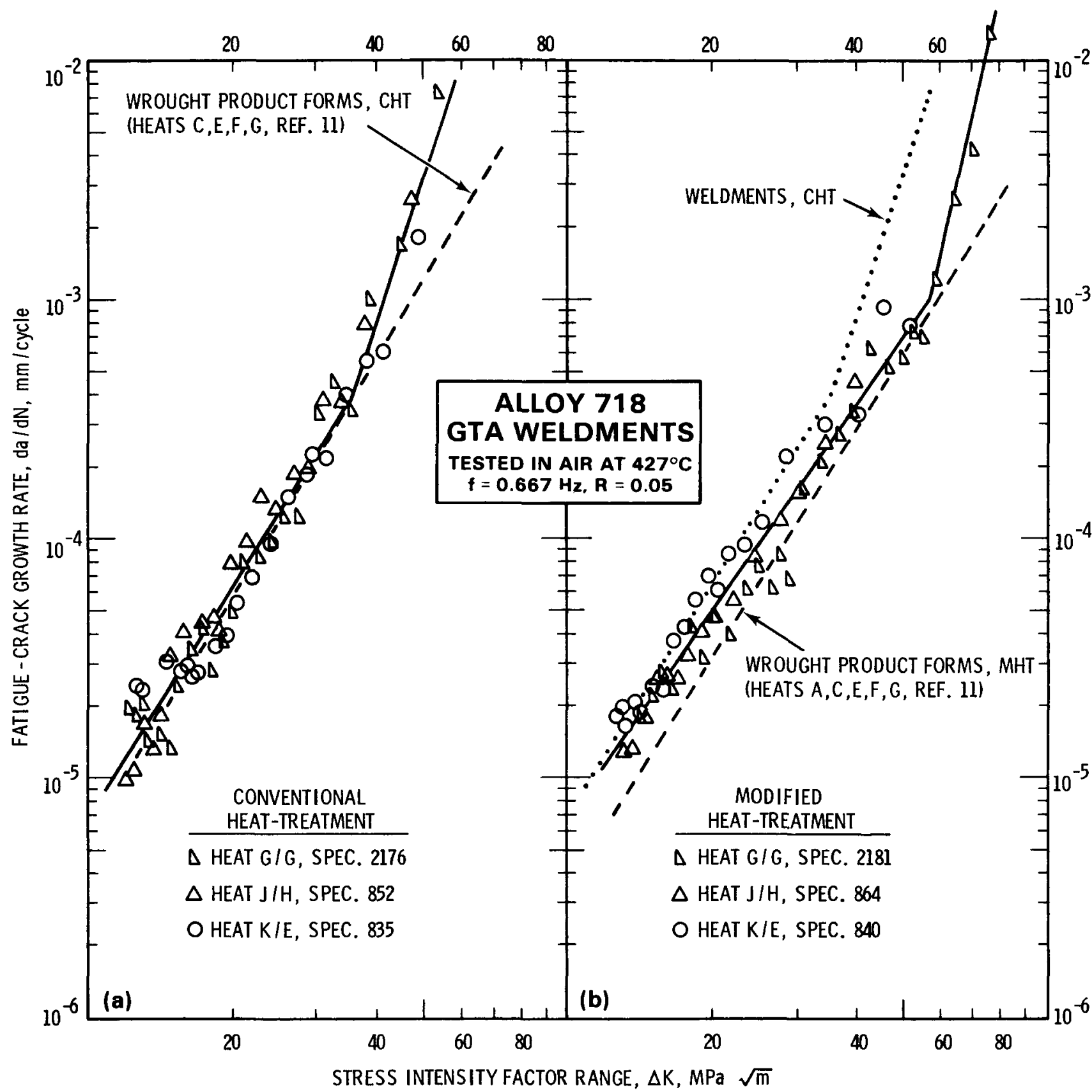

FIGURE 5. Fatigue-Crack Growth Rate Behavior of Alloy 718 Weldments Tested in Air at $427^{\circ} \mathrm{C}$. (Neg. 8009381-6) 


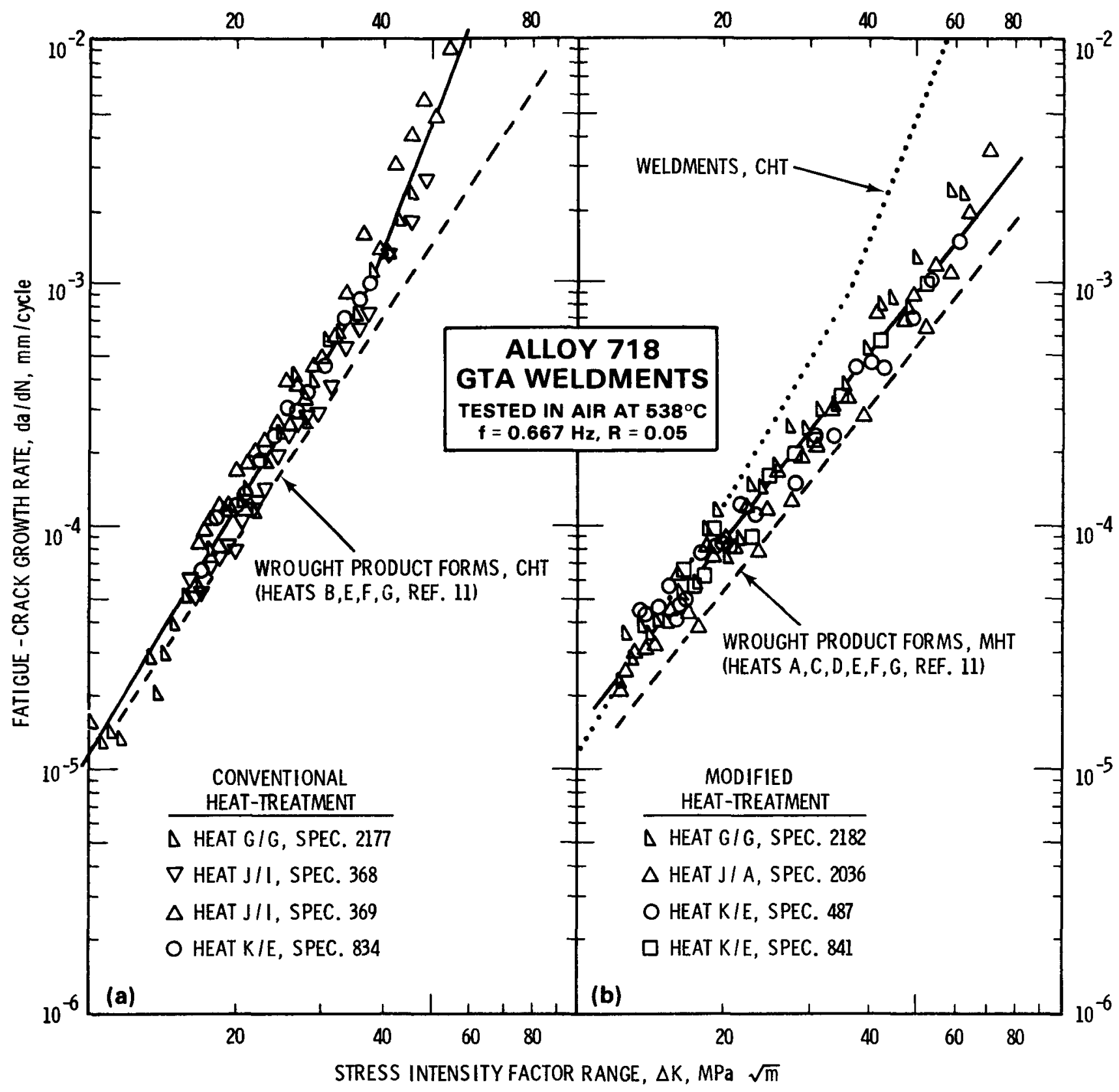

FIGURE 6. Fatigue-Crack Growth Rate Behavior of Alloy 718 weldments Tested in Air at $538^{\circ} \mathrm{C}$. (Neg. 8009381-8) 


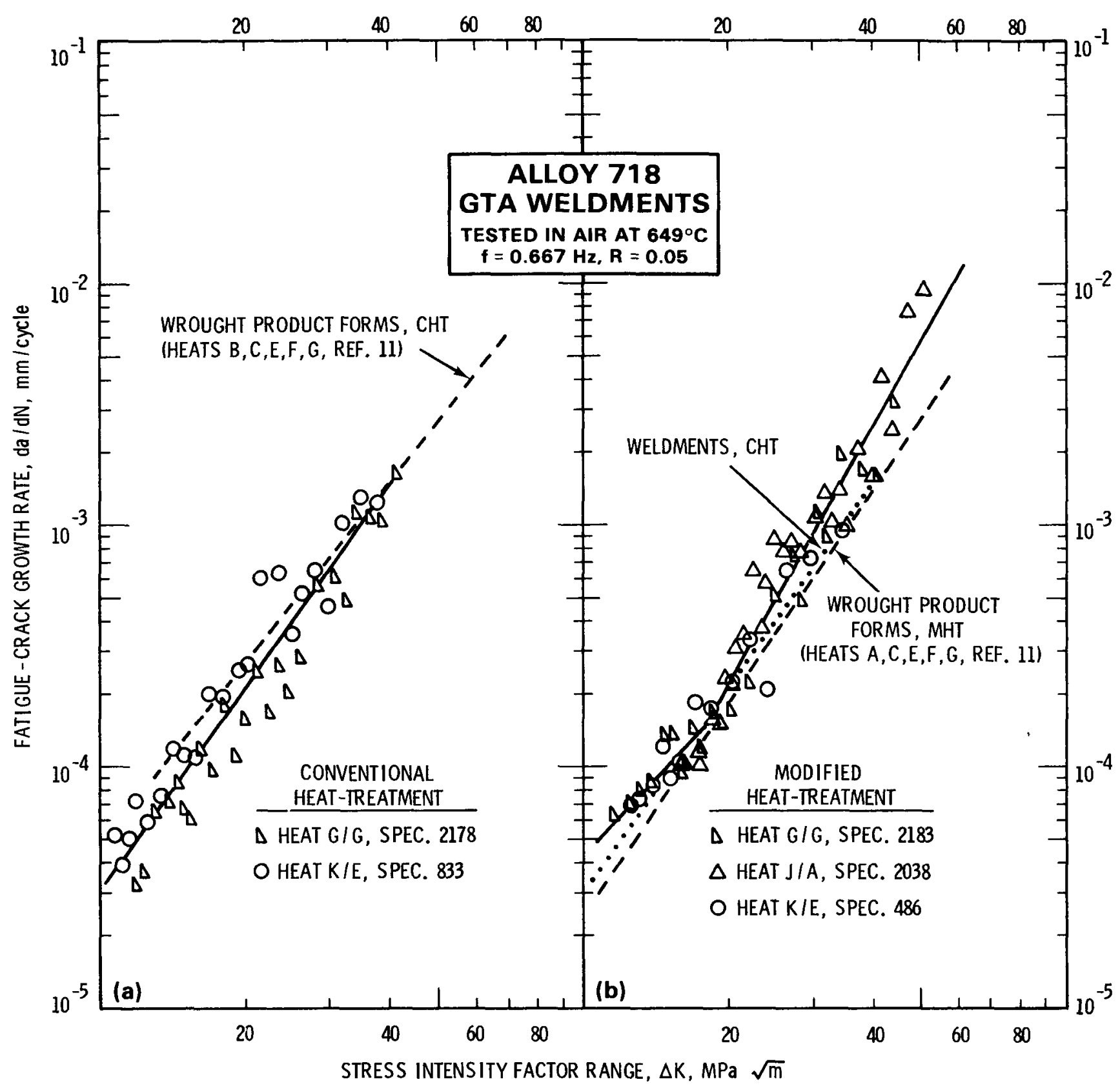

FIGURE 7. Fatigue-Crack Growth Rate Behavior of Alloy 718 Weldments Tested in Air at $649^{\circ} \mathrm{C}$. (Neg. 8009381-9) 
of those shown) for their respective specimens, yet specimens from other heats exhibited "normal" crack growth behavior out to $\mathrm{K}$-levels in excess of these failure levels. These differences could be due to heat-to-heat variations in the toughness of the weldments or, in the case of the results in Figure $4 \mathrm{~b}$, could be due to instability being achieved at a lower level in the smaller specimen (see Table 3 for a size comparison between specimens 2039 and 2180).

Heat-to-heat variations in the crack growth response have been observed in previous studies $(8,11,12,20,21)$ on wrought Alloy 718 . Therefore, one of the primary objectives of the present study was to investigate the possibility of similar heat-to-heat variations in the crack growth behavior of Alloy 718 weldments. In general, the results of Figures 3-7 where two or three heats of filler metal have been studied, suggest that there is little or no apparent heat-to-heat variation in the results. It should be emphasized, however, that the study on weldments incorporates at most three heats, while the study on wrought products $(11,12)$ examined seven heats. Since the cause(s) of heat-to-heat variability in wrought Alloy 718 has not been clearly identified, $(11,12)$ it is not safe to assume that heat-to-heat variability does not exist in Alloy 718 weldments. Clearly, the testing of additional heats of filler metal (or the modification of welding parameters) might incorporate these unknown factors in such a way as to produce heat-to-heat variations.

The results for conventionally-treated weldments tested at room temperature (Figure 3a) do suggest some heat-to-heat variability. This is illustrated by the relatively large standard errors of estimate and scatter factors that result if the data for Specimens 862 and 2175 are included in a single regression (see Table 6). However, this is about the only case where a heat-to-heat variation may be present.

Three heats of filler metal were utilized in this study but, as discussed earlier, several different heats of base metal were employed (shown as the second letter in the heat designations). It is not believed that utilizing 
TABLE 6

$$
\begin{gathered}
\text { CRACK GROWTH EQUATION CONSTANTS }(a) \\
\frac{d a}{d N}=c(\Delta K)^{n} \text { or } \log (d a / d N)=\log c+n \log (\Delta K)
\end{gathered}
$$

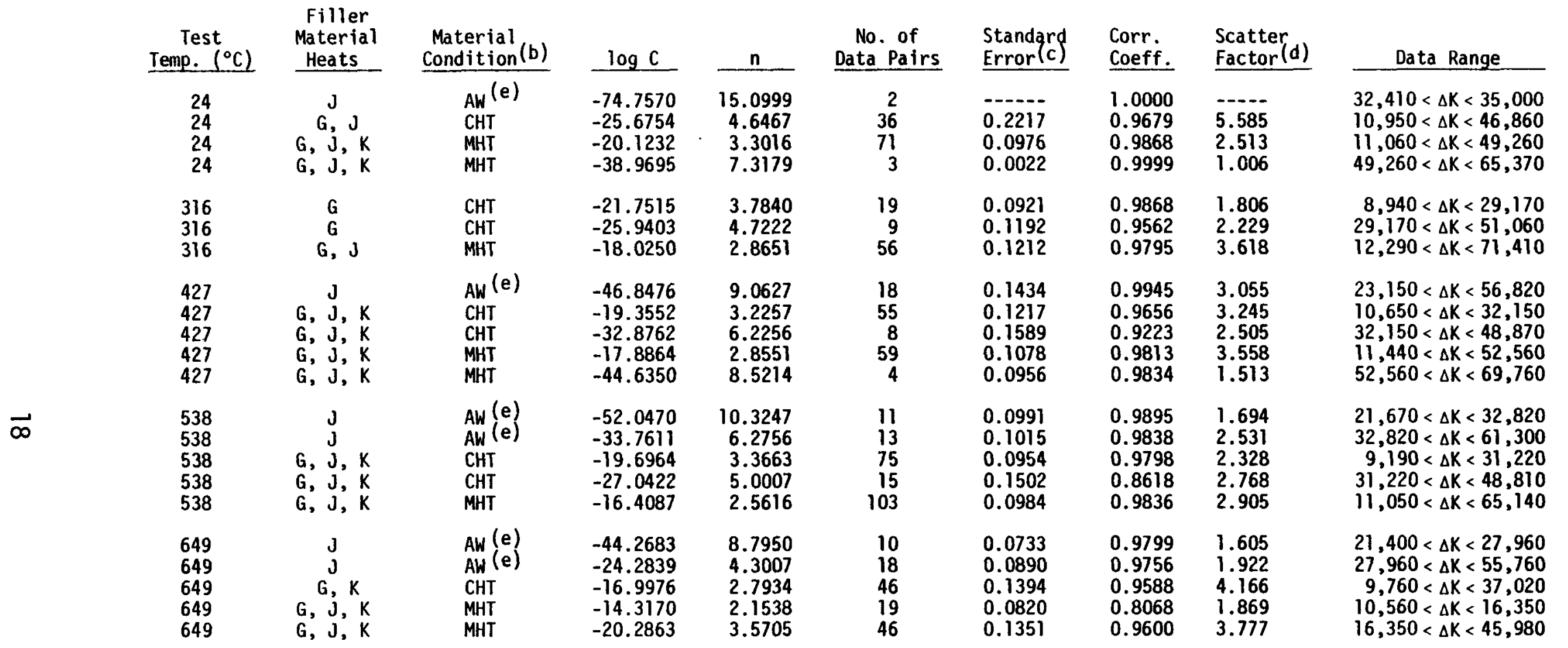

(a) Units: da/dN $=$ inch/cycle, $\Delta K=p s i \sqrt{i n}$

Conversion to SI Units: (inch/cycle) $(25.4)=\mathrm{mm} / \mathrm{cycle}$

(b) ${ }_{\text {AW }}=$ As-Welded

$\mathrm{CHT}=$ Conventional Heat-Treatment

MHT = Modified Heat-Treatment

(c) Standard error of estimate on $\log (\mathrm{da} / \mathrm{dN})$

(d) Total scatter factor on $d a / d N$

(e) Fatigue results for the as-welded material apply only to the weld geometry and specimen configuration used in this study. 
different heats of base metal influenced the results because the specimens were machined such that crack extension took place in the center of the deposited weld metal. Hence dilution and mixing of the base metal in this region would have been minimal, and no significance is attached to the use of different heats of base metal.

Previous studies $(2,3)$ have shown that somewhat lower crack growth rates are observed in weldments given the modified post-weld heat-treatment than in those given the conventional treatment. The regression lines for the two different post-weld heat-treatments are compared in the right half of Figures 3-7. With the exception of the results at $649^{\circ} \mathrm{C}$, the trend of lower crack growth rates in weldments given the modified treatment is observed in each case. The difference between conventional and modified treatments is especially pronounced at the higher levels of $\Delta K$, and this could be due, in part, to the generally superior fracture resistance exhibited by weldments given the modified heat-treatment. ${ }^{(19)}$ This will be discussed in more detail later.

Reference 3 suggested that there was somewhat greater data scatter associated with the testing of Alloy 718 weldments than with the testing of Alloy 718 plate. However, three measures of data variability (standard error of estimate, correlation coefficient, and scatter factor) have been included in the regression results shown in Table 6, and comparison of these parameters with similar measures for other investigations of Alloy 718 wrought material $(11,13)$ and weldments $(4,5)$ do not reveal significant differences in data variability between weldments and wrought forms of Alloy 718 . Somewhat more irregular crack extension paths are sometimes observed in the testing of Alloy 718 weldments, but this apparently does not manifest itself in greater data variability. Reference 22 suggested that a scatter factor of 2.0 was normal for multiple intralaboratory tests on a single wellbehaved heat of steel at room temperature, and a factor of 3.0 for multiple interlaboratory tests on the same steel. Reference 23 suggested that a scatter factor of 2.75 for multiple tests on a single heat of austenitic steel might be normal for intralaboratory elevated temperature tests; the 
higher factor being due to the increased difficulty of measuring crack lengths at elevated temperatures. The scatter factors listed in Table 6 are, in some cases, higher than these factors, but in general are quite consistent with similar variability measures for previous studies $(4,5,11,13)$ on Alloy 718 weldments and wrought forms. Hence, it seems reasonable to assume that this level of variability is typical of multiple tests on Alloy 718.

\section{B. AS-WELDED MATERIAL}

Applications occasionally arise where it may be neither practical nor necessary to employ post-welding heat-treatment on Alloy 718 weldments. When this is done, there is a significant lowering of tensile properties (see Table 5), accompanied by a significant increase in fracture toughness, (19) relative to material receiving post-weld heat-treatment. Because of these occasional applications, a limited amount of fatigue-crack growth rate testing was conducted on as-welded Alloy 718 from a single heat of filler metal.

These results are given in Figures 8 and 9 for test temperatures of 24,427 , 538 and $649^{\circ} \mathrm{C}$. Also shown, for comparison purposes, are the least-squares regression lines from the previous section for heat-treated weldments tested under similar conditions. The difference between the crack propagation behavior of the weldments tested in the as-welded condition versus those tested in the heat-treated conditions is dramatic! At all four test temperatures, the crack growth rates in the as-welded condition are significantly lower (e.g., up to a factor of 100 in Figure 9a) than those for the heattreated conditions. This trend is especially apparent at the lower values of $\Delta K$, as there is a tendency for the growth rates in as-welded material to approach those for heat-treated materials at the higher values of $\Delta \mathrm{K}$.

This dramatic difference in crack growth behavior is attributed to compressive residual stresses in the as-welded material. The influence of residual stresses on the fatigue response of welds is discussed in more detail in 


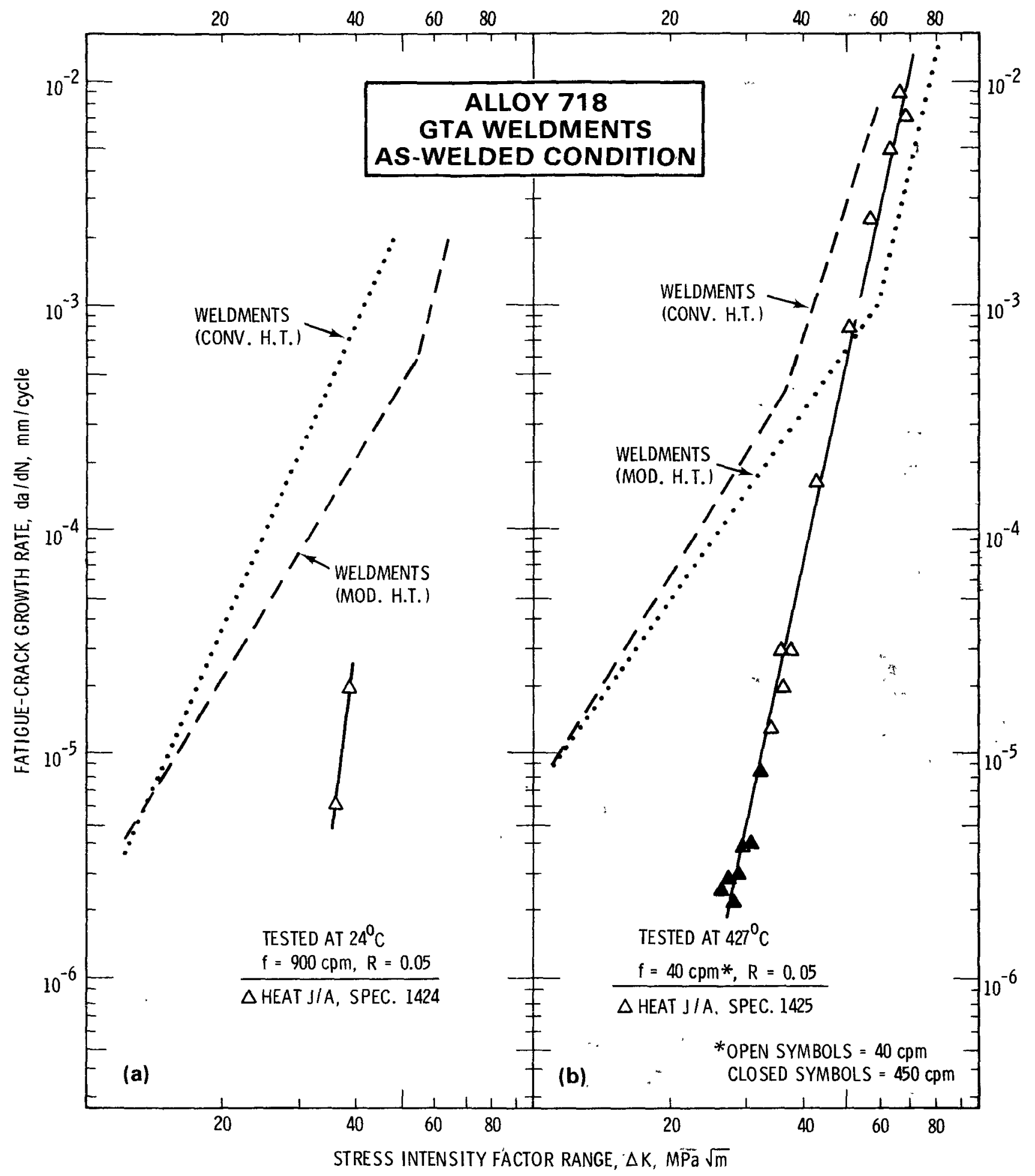

FIGURE 8. Fatigue-Crack Growth Rate Behavior of Alioy 718 Weldments in the As-Welded Condition Tested in Air at $24^{\circ} \mathrm{C}$ and $427^{\circ} \mathrm{C}$.

(Neg. 8009381-5) 


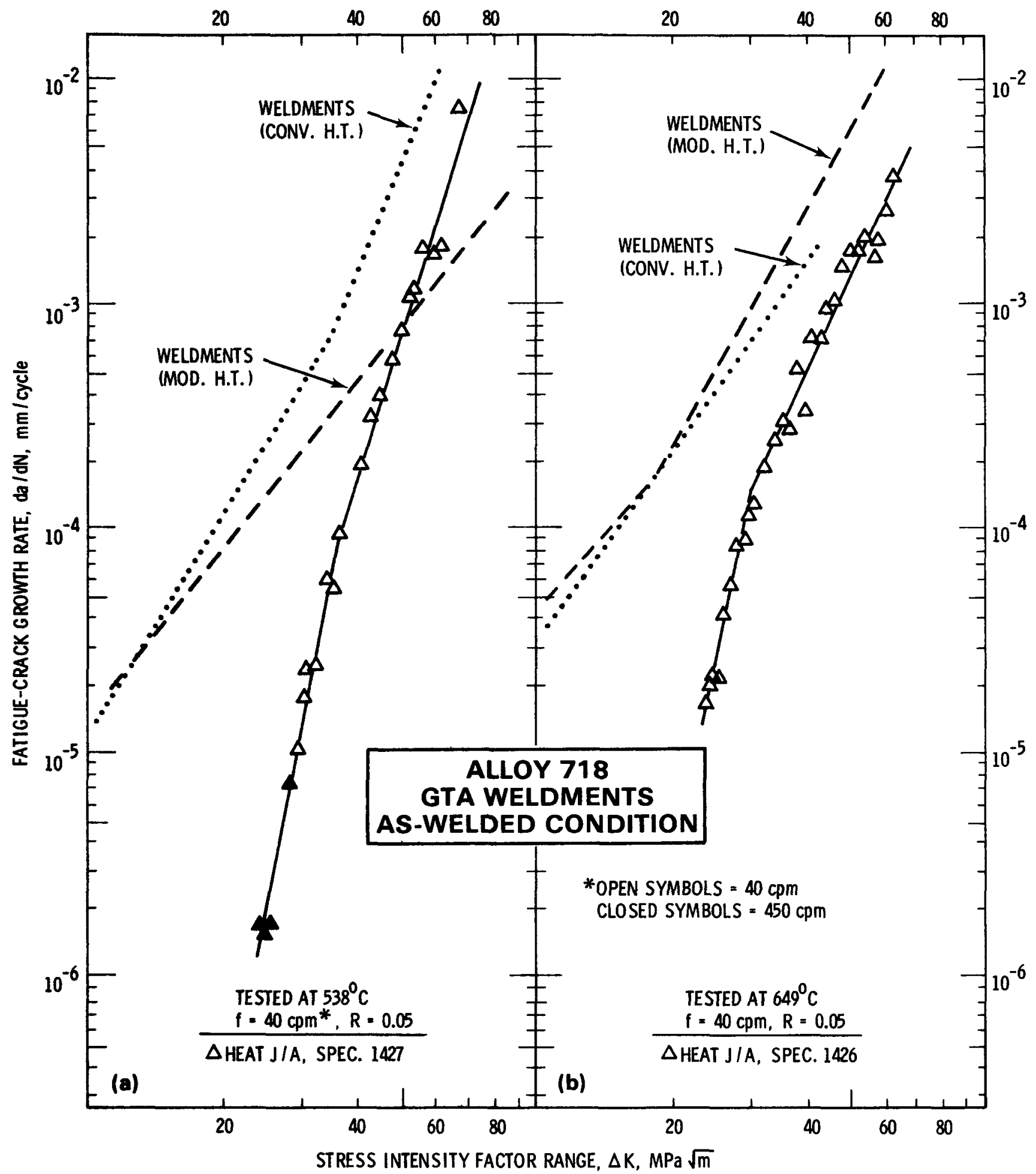

FIGURE 9. Fatigue-Crack Growth Rate Behavior of Alloy 718 Weldments in the As-Welded Condition Tested in Air at $538^{\circ} \mathrm{C}$ and $649^{\circ} \mathrm{C}$.

(Neg. 8009381-4) 
the companion paper. (14) It is noted, however, that the magnitude of the residual stresses is dependent on many variables such as welding process, weld geometry as well as specimen configuration. Therefore, the as-welded fatigue results reported herein reflect only the cyclic behavior for these particular weld specimens, and do not represent the true material behavior. 


\section{Blank Page}




\section{CONCLUSIONS}

The fatigue-crack propagation behavior of three Alloy 718 GTA weldments was characterized at room and elevated temperatures using linear-elastic fracture mechanics techniques. The welds were tested in both conventional and modified post-weld heat-treatment conditions. In addition, a few specimens were studied in the as-welded condition. The results of this investigation are given below:

- Crack growth rates in the heat-treated welds were slightly higher than those exhibited by Alloy 718 wrought material, particularly at the higher $\Delta K$ levels.

- The three welds tested in this study exhibited little or no heat-toheat variation in cyclic behavior. The present results are not judged sufficient, however, to rule out the possibility of heat-to-heat differences in additional welds fabricated from different filler heats with different welding parameters.

- At low stress intensities, the fatigue behavior for the two heattreated welds was essentially the same. Under progressively higher $\Delta K$ conditions, however, weldments given the modified post-weld treatment exhibited lower crack growth rates. This improved fatigue response was attributed to the overall superior fracture resistance exhibited by the modified welds.

- In the low $\Delta K$ regime, fatigue-crack growth rates in the as-welded material were one to two orders of magnitude below growth rates exhibited by the heat-treated welds. The dramatic improvement in fatigue resistance was attributed to the presence of compressive residual stresses in the as-welded condition. 
Blank Page 


\section{REFERENCES}

1. H. G. Popp and A. Coles, "Subcritical Crack Growth Criteria for Inconel 718 at Elevated Temperatures," in Proceedings of the Air Force Conference on Fatigue and Fracture of Aircraft Structures and Materials, AFFDL TR 70-144, Air Force Flight Dynamics Laboratory, pp. 71-86, 1970.

2. L. A. James, Fatigue-Crack Propagation Behavior of Inconel 718, HEDLTME 75-80, Hanford Engineering Development Laboratory, Richland, WA, September 1975.

3. L. A. James, "Fatigue-Crack Growth in Inconel 718 Weldments at Elevated Temperatures," Welding Journal Research Supplement 57, No. 1, pp. 17s23s, January 1978.

4. L. A. James, The Effect of Product Form Upon Fatigue-Crack Growth Behavior in Alloy 718 - Additional Results, HEDL-TME 80-49, Hanford Engineering Development Laboratory, Richland, WA, 1980.

5. L. A. James and W. J. Mills, "Fatigue-Crack Propagation Behavior of Defective Weldments," HEDL-SA 2172, Hanford Engineering Development Laboratory, Richland, WA, 1980 (to be published in International Journal of Pressure Vessel and Piping, 1981).

6. L. A. James, Effect of Fast Neutron Irradiation Upon Fatigue-Crack Growth Behavior of Precipitation-Hardened Superalloys - Interim Report, HEDL-TME 79-80, Hanford Engineering Development Laboratory, Richland, WA, January 1980.

7. L. A. James, Fatigue-Crack Growth Behavior in Dissimilar Metal Weldments, HEDL-TME 76-93, Hanford Engineering Development Laboratory, RichTand, WA, March 1977.

8. L. A. James, "The Effect of Temperature Upon the Fatigue-Crack Growth Behavior of Two Nickel-Base Alloys," Journal of Engineering Materials and Technology, 95, No. 4, pp. 254-256, October 1973.

9. W. J. Mills and L. A. James, "Effect of Heat Treatment on Elevated Temperature Fatigue Crack Growth Behavior of Two Heats of Alloy 718," ASME Paper 78-WA/PVP-3, New York, December 1978.

10. W. J. Mills and L. A. James, "The Fatigue-Crack Propagation Response of Two Nickel-Base Alloys in a Liquid Sodium Environment," Journal of Engineering Materials and Technology, 101, No. 3, pp. 205-213, July 1979.

11. L. A. James and W. J. Mil1s, Effect of Heat-Treatment and Heat-to-Heat Variations in the Fatigue-Crack Growth Response of Alloy 718 - Part I: Macroscopic Observations, HEDL-TME 80-9, Hanford Engineering Development Laboratory, Richland, WA, Apri1 1980. 
12. W. J. Mills and L. A. James, Effect of Heat-Treatment and Heat-to-Heat Variations in the Fatigue Crack Growth Response of Alloy 718 - Part II: Microscopic Observations, HEDL-TME 80-10, Hanford Engineering Development Laboratory, Richland, WA, April 1980.

13. L. A. James, The Effect of Product Form Upon Fatigue-Crack Growth Behavior in AT10y 718, HEDL-TME 80-11, Hanford Engineering Development Laboratory, Richland, WA, April 1980.

14. W. J. Mills and L. A. James, Effect of Heat Treatment Upon the FatigueCrack Growth Behavior of Alloy 718 Weldments - Part II: Microscopic Response, HEDL-TME 81-13, Hanford Engineering Development Laboratory, Richland, WA, 1981.

15. G. R. Smolik and W. G. Reuter, Heat Treatment Investigations for Welded Inconel 718 Pressure Vessels for the Power Burst Factility, ANCR-1227, Aerojet Nuclear Company, Idaho Falls, ID, 1977.

16. W. G. Reuter, Design Data for the 1/4-Inch Thick Alloy 718 In-Pile Tube, TREE-NUREG-1087, EG\&G Idaho Inc., Idaho Fal1s, ID, 1977.

17. L. A. James, Specimen Size Considerations in Fatigue-Crack Growth Rate Testing, HEDL-TME 78-99, Hanford Engineering Development Laboratory, Richland, WA, December 1978.

18. G. R. Smolik and G. E. Korth, Reference Heat of Alloy 718 for Department of Energy Programs, TREE-1253, EG\&G Idaho Inc., Idaho Fa11s, ID, 1978.

19. W. J. Mills, Effect of Heat Treatment on the Elevated Temperature Tensile and Fracture Toughness Behavior of Alloy 718 Weldments, HEDLTME 80-18, Hanford Engineering Development Laboratory, Rich7and, WA, May 1980.

20. H. H. Smith and D. J. Michel, "Fatigue Crack Propagation and Deformation Mode in Alloy 718 at Elevated Temperatures," in Ductility and Toughness Considerations in Elevated Temperature Service, Series MPC-8, pp. 225246, ASME, 1978.

21. K. Sadananda and P. Shahinian, "Effect of Microstructure on CreepFatigue Crack Growth in Alloy 718," Res Mechanica, 1, pp. 109-128, 1980 .

22. W. G. Clark and S. J. Hudak, "Variability in Fatigue Crack Growth Rate Testing," Journal of Testing and Evaluation, 3, No. 6, pp. 454-476, 1975.

23. L. A. James, "Effect of Heat-to-Heat and Melt Practice Variations Upon Fatigue Crack Growth in Two Austenitic Steels," in Properties of Austenitic Stainless Steels and Their Weld Metals, ASTM STP 679, pp. 3-16, 1979. 
HEDL-TME 81-12

UC-79b, $h$

\section{DISTRIBUTION}

$\underline{U C-79}$ (122)

$\underline{U C-79 b}$ (36)

$\underline{U C-79 h \quad(27)}$

DOE/RRT-HQ (2)

MaiT Stop B-107

Washington, DC 20545

Program Division Director

DOE/FFTFPO (5)

Director

HEDL (38)

$\begin{array}{ll}\text { TK Bierlein } & \text { W/A-1 } \\ \text { LD Blackburn } & \text { W/A-40 } \\ \text { WF Brown } & \text { W/C-19 } \\ \text { KW Carlson } & \text { W/A-40 } \\ \text { DJ Criswe11 } & \text { W/A-40 } \\ \text { DG Doran } & \text { W/A-57 } \\ \text { AM Ermi } & \text { W/A-58 } \\ \text { DS Ge1les } & \text { W/A-57 } \\ \text { DL Greenslade } & \text { W/A-40 } \\ \text { GL Guthrie } & \text { W/C-39 } \\ \text { GW Hollenberg } & \text { W/A-59 } \\ \text { WL Hu } & \text { W/A-53 } \\ \text { LA James (2) } & \text { W/A-40 } \\ \text { GD Johnson } & \text { W/A-58 } \\ \text { MD Jones } & \text { W/A-40 } \\ \text { RL Knecht } & \text { W/A-40 } \\ \text { GC Massie } & \text { W/A-40 }\end{array}$

B. Mastel

WJ Mills (2)

NF Panayotou

WE Roake

CT Schaede 1

LK Severud

WF Sheely

JL Straalsund

WD Themar

AL Ward

JA Williams

GL Wire

Central Files (5)

Publ Services (2)
$W / A-60$

W/A-40

W/A-53

W/C-16

W/A-46

$W / C-98$

W/A-62

$W / A-61$

$W / A-40$

W/A-40

W/A-124

W/A-58

W/C-110

$W / C-115$

\section{DO NOT MICROFILM \\ THIS PACE}

